\title{
Conditions for Single Strand Conformation Polymorphism (SSCP) Analysis with Broad Applicability: A Study on the Effects of Acrylamide, Buffer and Glycerol Concentrations in SSCP Analysis of Exons of the p53 Gene ${ }^{1}$ )
}

\author{
Winfried Teschauer ${ }^{1}$,Thomas Mussack ${ }^{2}$,Andreas Braun ${ }^{3}$, Helmut Waldner $^{2}$ and Edwin Fink ${ }^{1}$
}

1 Abteilung für Klinische Chemie und Klinische Biochemie in der Chirurgischen Klinik und Poliklinik

2 Chirurgische Klinik und Poliklinik, Klinikum Innenstadt

3 Abteilung für Klinische Chemie, Dr. v. Haunersches Kinderspital Ludwig-Maximilians-Universität, München, Germany

Summary: We examined the influence of electrophoretic conditions on the detectability of small sequence alterations in DNA fragments by single strand conformation polymorphism (SSCP) analysis. Three acrylamide concentrations, $7.5,14$ and $20 \%$, were selected, and all three gel types were prepared with four different Tris/borate/EDTA buffer concentrations. In addition, all these twelve gels were prepared both with and without $10 \%$ glycerol. All electrophoretic runs were performed at ambient temperature of $20-24^{\circ} \mathrm{C}$. The resulting 24 different electrophoretic conditions were used for the SSCP analysis of DNA fragments of exons 5, 7 and 8 of the human p53 gene; the results were evaluated primarily in relation to detectability of mutants. Six out of the 24 conditions permitted the detection of all mutants. For practical reasons, $14 \%$ acrylamide, $44.5 \mathrm{mmol} / 1$ Tris, $44.5 \mathrm{mmol} / 1$ boric acid, $1 \mathrm{mmol} / 1$ EDTA, $\mathrm{pH}$ 8.0, with and without addition of glycerol was chosen as the most suitable. These "selected conditions" were applied in the SSCP analysis of an arbitrarily chosen set of mutant DNA fragments with single base exchanges, and all but one of seven mutants were detected in the gel system containing glycerol.

Our results indicate that the set of "selected conditions" is of broad applicability, permitting the detection of even small sequence differences like single base exchanges with high reliability. It should prove especially useful in screening for unknown mutations.

\section{Introduction}

Techniques for the detection of naturally occurring gene mutations are of great importance to research in genetics, and a large variety of methods is currently employed (reviewed in 1.c. (1)). No single method is applicable to all situations; in each case the most suitable method for the respective problem has to be selected. Probably the most widely used method for detecting small alterations of known genes is the single strand conformation polymorphism analysis, SSCP, introduced in 1989 by Orita et al. (2). The DNA segment of interest is amplified by polymerase chain reaction (PCR), the strands of the PCR product are separated by denaturation, then submitted to gel electrophoresis under non-denaturing conditions. The two single strands assume individual three-dimensional conformations which cause them to migrate differently during electrophoresis. If the PCR products of wild-

\footnotetext{
1) This work was supported in part by a grant of the Dr. JohannesHeidenhain-Stiftung.
}

type and mutant target DNA are electrophoresed side by side, a sequence difference of the mutant may be revealed by different migration of one or both of the mutant single strands. For detection of the amplification products in the gel, radioactive labelling during the amplification reaction followed by autoradiography, or non-radioactive methods such as silver-staining (3) or ethidium bromide staining (4) may be employed.

Orita et al. (2) used a polyacrylamide gel of 5 or $6 \%$, and found that bands were best resolved when the gel contained $10 \%$ glycerol and was run at room temperature. According to recent publications on SSCP analysis of p53 exons, most authors use conditions very similar to those of Orita et al. (2), i.e. 5-8\% polyacrylamide, $5-10 \%$ glycerol and a temperature between $4{ }^{\circ} \mathrm{C}$ and room temperature. As we had obtained good band resolution in gels of $20 \%$ polyacrylamide in the absence of glycerol, we decided to conduct a systematic study on the effects of the concentration of acrylamide, the concentration of buffer for gel preparation and the presence of glycerol. 


\section{Materials and Methods}

\section{Deoxyribonucleic acid preparation}

Wild-type DNA was prepared from peripheral leukocytes of a healthy volunteer. DNA with mutations in the p53 gene was from a cultured epithelial cell line, $\mathrm{HaCaT}$, with known mutations in exons 5 and $8(5,6)$, from a cell line derived from breast carcinoma which had an unknown mutation in exon 8 , and from the tissue of a colorectal carcinoma, which had an unknown mutation in exon 7. DNA was extracted from samples by methods similar to those described by Sambrook et al. (7).

\section{Polymerase chain reaction}

DNA segments of the p53 gene

We used the same primers as Unsal et al. (8) and Chozick et al. (9); these represent sequences flanking exons 5, 7 and 8 of the p53 gene (10), and were synthesized by MWG-Biotech (Ebersberg, Germany). The sequences were

E5f: 5'-TTCCTCTTCCTGCAGTACTC-3', E5r: 5'-TGCTCACCATCGCTATCTGA-3', E7f: 5'-GTGTTGTCTCCTAGGTTGGC-3', E7r: 5'-CAAGTGGCTCCTGACCTGGA-3', E8f: 5'-CTGAGTAGTGGTAATCTACTG-3', E8r: 5'-TGCTTGCTTACCTCGCTTAGT-3'.

The size of the expected PCR products was 206, 139 and 156 base pairs, respectively. Genomic DNA $(1 \mu \mathrm{g})$ was amplified in a $50 \mu \mathrm{l}$ reaction mixture containing $1.25 \mathrm{U}$ Taq DNA polymerase (Pharmacia, 27-0799-01), $100 \mathrm{pmol}$ of each primer, $20 \mathrm{nmol}$ of each deoxyribonucleoside triphosphate, $1.5 \mathrm{mmol} / 1 \mathrm{MgCl}_{2}, 50 \mathrm{mmol} / \mathrm{l}$ $\mathrm{KCl}, 10 \mathrm{mmol} / 1 \mathrm{Tris} / \mathrm{HCl}, \mathrm{pH}$ 9.0. The reaction mixtures were overlaid with $50 \mu$ lof mineral oil and then subjected to PCR amplification consisting of one cycle of $94^{\circ} \mathrm{C}$ for $5 \mathrm{~min}, 56^{\circ} \mathrm{C}$ for $1 \mathrm{~min}$, $72^{\circ} \mathrm{C}$ for $1 \mathrm{~min}$ and 34 cycles of $94^{\circ} \mathrm{C}$ for $1 \mathrm{~min}, 56^{\circ} \mathrm{C}$ for $1 \mathrm{~min}$, $72^{\circ} \mathrm{C}$ for $1 \mathrm{~min}$ in a Thermal Cycler (Perkin-Elmer Cetus, N8010150).

For sequence determination, the PCR products were purified using a QIAquick PCR purification kit (QIAGEN, Hilden, Germany) and directly sequenced by using forward and reverse PCR primers to identify or confirm mutations. Sequencing was done by MEDIGENE (Martinsried, Germany) by fluorescence-based dideoxy-termination methods using an Applied Biosystems Model 373 automated DNA sequencer.

DNA segments of the human $\beta$-globin gene and the gene responsible for $X$-chromosomal adrenoleukodystrophy

The general applicability of the "selected conditions" was examined by performing SSCP analyses of a 233 base pair fragment specific for intron 2 of the human $\beta$-globin gene (amplification as described by Braun et al., (11)) and of segments of 202, 213, 239 and 227 base pairs of exons 1, 5, 6 and 9 of the gene responsible for X-chromosomal adrenoleukodystrophy (amplification conditions and the sequences of these novel mutants will be published elsewhere in detail).

\section{Electrophoresis}

The electrophoresis apparatus was a Hoefer dual vertical slab unit SE 600 without a cooling system. The slab gels $(140 \times 160 \times 1.5$ $\mathrm{mm}$ ) with 75,140 or $200 \mathrm{~g} / \mathrm{l}$ total acrylamide concentration (acrylamide : bisacrylamide $=37.5: 1$ ) in Tris/borate/EDTA buffer, $\mathrm{pH} 8.3$

( $44.5 \mathrm{mmol} / \mathrm{l}$ Tris; $44.5 \mathrm{mmol} / \mathrm{l}$ boric acid; $1 \mathrm{mmol} / \mathrm{l}$ EDTA $89.0 \mathrm{mmol} / \mathrm{l}$ Tris; $\quad 89.0 \mathrm{mmol} / \mathrm{l}$ boric acid; $2 \mathrm{mmol} / \mathrm{l}$ EDTA $133.5 \mathrm{mmol} / \mathrm{l}$ Tris; $133.5 \mathrm{mmol} / \mathrm{l}$ boric acid; $3 \mathrm{mmol} / 1$ EDTA $178.0 \mathrm{mmol} / \mathrm{l}$ Tris; $178.0 \mathrm{mmol} / \mathrm{l}$ boric acid; $4 \mathrm{mmol} / \mathrm{l}$ EDTA) were prepared both with and without $10 \%$ glycerol. In the $200 \mathrm{~g} / \mathrm{l}$ gel incomplete polymerization was observed at sites where the gel was in contact with the comb. This problem could be overcome by a $3 \%$ spacer gel which was used routinely with all types of slab gel. In all experiments the electrophoresis buffer in the tanks was Tris $44.5 \mathrm{mmol} / \mathrm{l}$; boric acid $44.5 \mathrm{mmol} / \mathrm{l}$; EDTA $1 \mathrm{mmol} / \mathrm{l}$, $\mathrm{pH} 8.3$.

The PCR reaction mixture $(2$ or $4 \mu \mathrm{l})$ was diluted with $20 \mu \mathrm{l}$ of $95 \%$ formamide in water, $20 \mathrm{mmol} / \mathrm{l} \mathrm{Na}{ }_{2}$ EDTA, $0.5 \mathrm{~g} / 1$ bromophenol blue, heat denatured at $96^{\circ} \mathrm{C}$ for $5 \mathrm{~min}$ and immediately chilled in ice.

Electrophoresis was performed at room temperature $\left(20-24^{\circ} \mathrm{C}\right)$, two gels containing the same acrylamide concentration being run in one chamber. The electrophoresis running times without glycerol were $4-6 \mathrm{~h}$ for $75 \mathrm{~g} / \mathrm{l}$ at $150 \mathrm{~V}, 14 \mathrm{~h}$ for $14 \mathrm{~g} / 1$ at $105 \mathrm{~V}$ and $14 \mathrm{~h}$ for the $200 \mathrm{~g} / \mathrm{l}$ gels at $180 \mathrm{~V}$. DNA bands were visualized by staining the gels according to the method of Riesner et al. (12): the gel was shaken for $3 \mathrm{~min}$ in ethanol/acetic acid/water $(30+10+60$ by vol.), incubated for $20-45 \mathrm{~min}$ in $1 \mathrm{~g} / 1$ silver nitrate, then for $20 \mathrm{~min}$ in $15 \mathrm{~g} / 1$ sodium hydroxide, $0.1 \mathrm{~g} / 1$ sodium borohydride, $1.5 \mathrm{~g} / \mathrm{l}$ formaldehyde. The staining was stopped by transferring the gel into $5 \%$ acetic acid. A standard of double-stranded DNA (821 705, Boehringer, Mannheim, Germany) was applied to all gels.

\section{Results}

The effects of various electrophoresis conditions on the mobilities of single stranded PCR products of exons 5 , 7 and 8 of the p53 gene were investigated, with a view to finding conditions which might be generally applicable in SSCP analysis. Three acrylamide concentrations were selected, 75, 140 and $200 \mathrm{~g} / \mathrm{l}$; all three types of gel were prepared with four buffer concentrations (cf. section "Electrophoresis"), and each of these twelve gels was prepared without or with $10 \%$ glycerol. Thus, a total of 24 different electrophoresis conditions was evaluated. The DNA molecules investigated were the PCR products of wild types and mutants of exons 5, 7 and 8 of human p53 gene.

\section{Effects of temperature}

It is well known that the temperature at which the nondenaturing polyacrylamide gel electrophoresis of single stranded DNA fragments is performed has a significant influence on the band pattern. In the present study the temperature effect was not investigated systematically, but all electrophoretic runs were carried out at room temperature, i.e. in the range of $20-24^{\circ} \mathrm{C}$. However, as several control experiments (results not shown here) demonstrated, it is essential that ambient temperature is within the range given; otherwise the band patterns may change dramatically. If the room temperature was significantly higher than the upper limit $\left(>25^{\circ} \mathrm{C}\right)$ it was necessary to use a thermostated electrophoretic unit in order to reproduce the same band patterns.

\section{Migration rate of double stranded DNA}

Influence of the various conditions on electrophoretic mobility was judged by the migration rate of double stranded DNA of a standard chain length, which was included in all electrophoretic rủns. As expected, an increase of the acrylamide concentration caused a 
lowering of the migration rate of the double stranded DNA fragments. When comparing gels of identical buffer concentrations and without glycerol, the migration rate in $200 \mathrm{~g} / \mathrm{l}$ gels was less than one third of that in the $75 \mathrm{~g} / 1$ gels. Addition of $10 \%$ glycerol to the gels reduced the migration rate significantly: in $75 \mathrm{~g} / 1$ gels to one half and in 140 and $200 \mathrm{~g} / \mathrm{l}$ gels even to one third. Consequently, the running time for $200 \mathrm{~g} / \mathrm{l}$ polyacrylamide gels in the presence of glycerol became unacceptably high, e.g. the 200 base pairs DNA migrated $7 \mathrm{~cm}$ in about $32 \mathrm{~h}$.

The buffer concentration of the gels had a moderate effect on the migration rate. When the buffer concentration was increased (cf. section "Electrophoresis") while applying the same voltage to the electrophoresis chamber, the migration rates were reduced by 6 to $17 \%$, with the highest reduction in $75 \mathrm{~g} / 1$ gels without glycerol.

\section{Migration of single stranded DNA}

The migration rates of single stranded DNA (ssDNA) fragments under non-denaturing conditions depend on the individual base sequences which cause the strands to assume specific secondary structures under the respective conditions. In our experience, no reliable prediction of the migration behaviour of ssDNA is possible, for example, the ssDNA molecules may migrate slower or faster than double stranded DNA (dsDNA) of identical chain length, though, in all examples presented

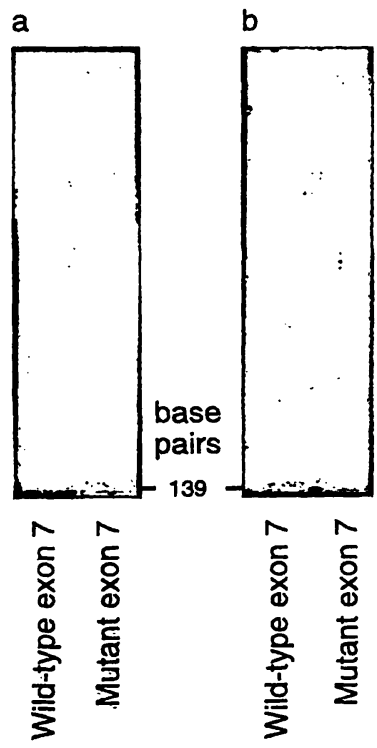

Fig. 1 Influence of electrophoretic conditions. The figure shows an extreme example of the dependence of band patterns on electrophoretic conditions. PCR products of wild-type and mutant exon 7 of the human p 53 gene were denatured and subjected to electrophoresis in two different gel systems.

a) $75 \mathrm{~g} / 1$ acrylamide, $178.0 \mathrm{mmol} / \mathrm{l} \mathrm{Tris} ; 178.0 \mathrm{mmol} / \mathrm{l}$ boric acid; $4 \mathrm{mmol} / \mathrm{l}$ EDTA, $10 \%$ glycerol;

b) $140 \mathrm{~g} / \mathrm{l}$ acrylamide, $44.5 \mathrm{mmol} / \mathrm{l}$ Tris; $44.5 \mathrm{mmol} / \mathrm{l}$ boric acid; $1 \mathrm{mmol} / \mathrm{l}$ EDTA; no glycerol. Double stranded DNA (size indicated) in the samples shows as an intense band at the bottom of each lane. here, the migration rate of ssDNA was lower than that of the corresponding dsDNA molecules.

The effect of electrophoretic conditions on the quality of separation of ssDNA molecules was judged from the appearance (diffuseness) and number of bands of the PCR products. Typical examples are shown in the figures, but it has to be added that the effects described here are not always equally clear for all PCR products and were generally better recognizable in the polyacrylamide gels themselves than in the photographs.

The number of discrete bands of the same PCR product varied with the electrophoretic conditions. For example, in the case of exon 7 we observed between three and four for the wild-type, and between three and eight bands for the mutant (fig. 1). The varying number of bands obviously reflects the fact that different electrophoretic conditions can significantly affect the numbers of coexisting conformations and/or their separation.

In $75 \mathrm{~g} / \mathrm{l}$ gels the bands had, in general, a more diffuse appearance than in the gels of higher acrylamide concentrations. Increasing the buffer concentrations in the $75 \mathrm{~g} / \mathrm{l}$ gels (without glycerol) as indicated in section "Electrophoresis" improved band separation (fig. 2) and, especially for mutant 2 of exon 8 , increased the number of bands. On the other hand, for the wild-type exon 5 (no figure shown) the increase from $44.5 \mathrm{mmol} / \mathrm{l}$ Tris;

a b d

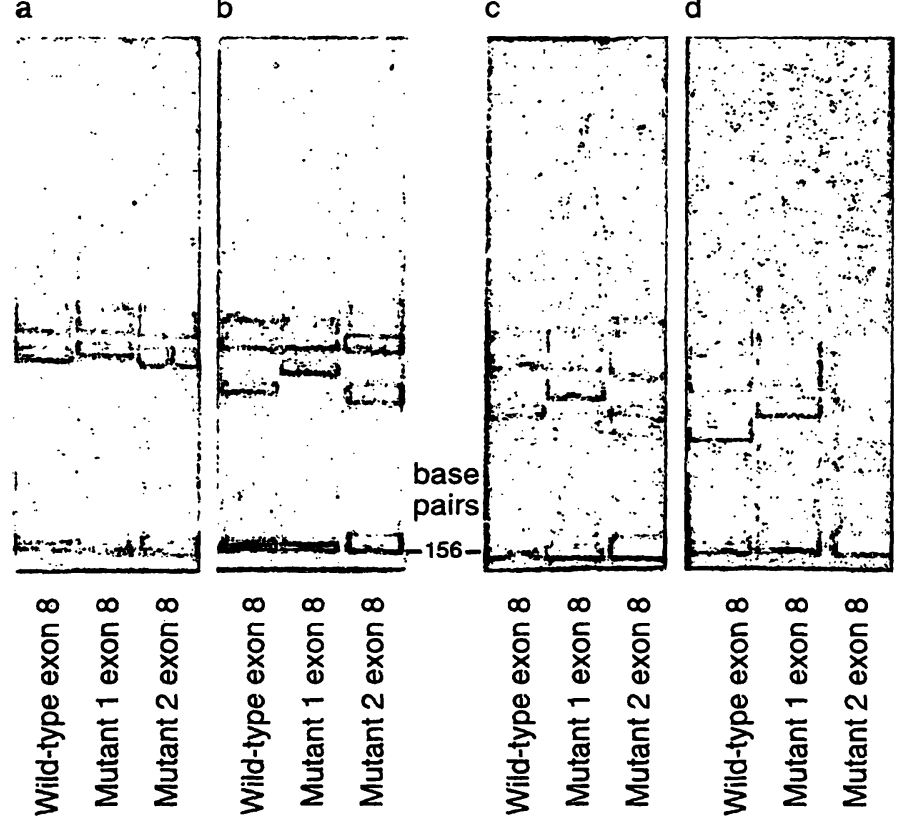

Fig. 2 Influence of different buffer concentrations in polyacrylamide gels without glycerol on the electrophoretic behaviour of ssDNA fragments. PCR products of wild type and two mutants of exon 8 of the human p53 gene were denatured and applied to 75 g/l polyacrylamide gels without glycerol. The gels contained different concentrations of buffer:

a) $44.5 \mathrm{mmol} / \mathrm{Tris} ; 44.5 \mathrm{mmol} / /$ boric acid; $1 \mathrm{mmol} / \mathrm{EDTA}$ b) $89.0 \mathrm{mmol} / \mathrm{l} \mathrm{Tris;} 89.0 \mathrm{mmol} / \mathrm{l}$ boric acid; $2 \mathrm{mmol} / \mathrm{l}$ EDTA c) $133.5 \mathrm{mmol} / / \mathrm{Tris} ; 133.5 \mathrm{mmol} / \mathrm{l}$ boric acid; $3 \mathrm{mmol} / \mathrm{EDTA}$ d) $178.0 \mathrm{mmol} / / \mathrm{Tris} ; 178.0 \mathrm{mmol} / \mathrm{l}$ boric acid; $4 \mathrm{mmol} / \mathrm{I} \mathrm{EDTA}$ Double stranded DNA (size indicated) in the samples shows as an intense band at the bottom of each lane. 
a

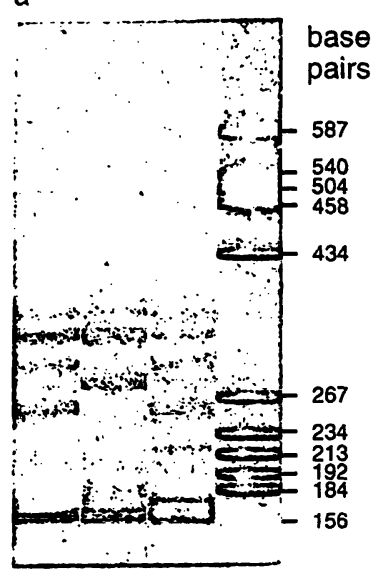

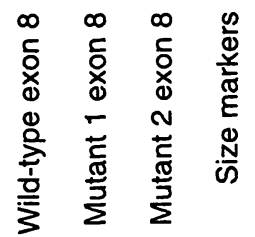

b

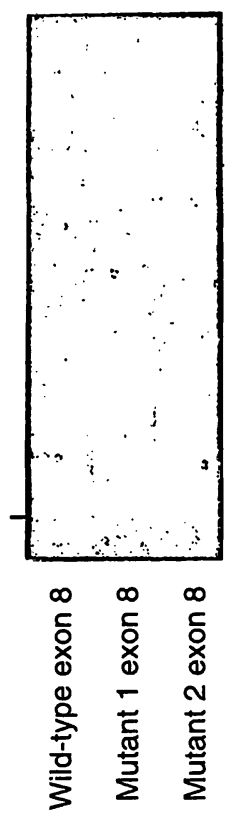

Fig. 3 Influence of different buffer concentrations, in polyacrylamide gels containing glycerol, on the electrophoretic behaviour of ssDNA fragments. PCR products of wild type and two mutants of exon 8 of the human p53 gene were denatured and applied to $75 \mathrm{~g} / 1$ polyacrylamide gels containing $10 \%$ glycerol. The gels contained different concentrations of buffer:

a) $44.5 \mathrm{mmol} / 1 \mathrm{Tris} ; 44.5 \mathrm{mmol} / \mathrm{l}$ boric acid; $1 \mathrm{mmol} / 1 \mathrm{EDTA}$; b) $178.0 \mathrm{mmol} / \mathrm{l}$ Tris; $178.0 \mathrm{mmol} / \mathrm{l}$ boric acid; $4 \mathrm{mmol} / \mathrm{l}$ EDTA. Double stranded DNA (size indicated) in the samples shows as an intense band at the bottom of each lane. The ladder of a size marker of double stranded DNA is also shown.

$44.5 \mathrm{mmol} / \mathrm{l}$ boric acid; $1 \mathrm{mmol} / \mathrm{l} \mathrm{EDTA}$ to $89.0 \mathrm{mmol} / \mathrm{l}$ Tris; $89.0 \mathrm{mmol} / \mathrm{l}$ boric acid; $2 \mathrm{mmol} / \mathrm{l}$ EDTA improved band separation, but a further increase to $133.5 \mathrm{mmol} / \mathrm{l}$ Tris; $133.5 \mathrm{mmol} / \mathrm{l}$ boric acid; $3 \mathrm{mmol} / \mathrm{l}$ EDTA had no clear effect, while the further increase resulted in a significant deterioration with the mutant becoming indistinguishable from the wild-type exon 5 .

The effect of glycerol in $75 \mathrm{~g} / \mathrm{l}$ gels is shown in figures $3 a$ and $3 b$, which differ from figures $2 a$ and $2 d$ in that the gels contained $10 \%$ glycerol. In the gels with both low buffer concentrations, the bands became somewhat less diffuse and better separated (lanes Wild-type exon 8 and Mutant 2 exon 8 in figs. 2a and 3a), but in both high buffer concentrations, band separation deteriorated significantly (figs. $2 \mathrm{~d}$ and $3 \mathrm{~b}$ ).

In $140 \mathrm{~g} / \mathrm{l}$ gels (fig. 4) the bands were sharper than in $75 \mathrm{~g} / \mathrm{l}$ gels and, without glycerol (fig. 4b), the best band separation being seen at both lower buffer concentrations. Addition of $10 \%$ glycerol (fig. 4a) improved band separation in the $140 \mathrm{~g} / \mathrm{l}$ gels at all buffer concentrations.

In the $200 \mathrm{~g} / \mathrm{l}$ gels (fig. 5) the band sharpness was further improved. However, as in the $140 \mathrm{~g} / \mathrm{l}$ gels, we observed that closely adjacent bands tended to become less well separated when the buffer concentration was raised; this is clearly shown in figures $5 \mathrm{a}(44.5 \mathrm{mmol} / \mathrm{l}$ Tris; $44.5 \mathrm{mmol} / \mathrm{l}$ boric acid; $1 \mathrm{mmol} / \mathrm{l}$ EDTA $)$ and $5 \mathrm{~d}(89.0$

a

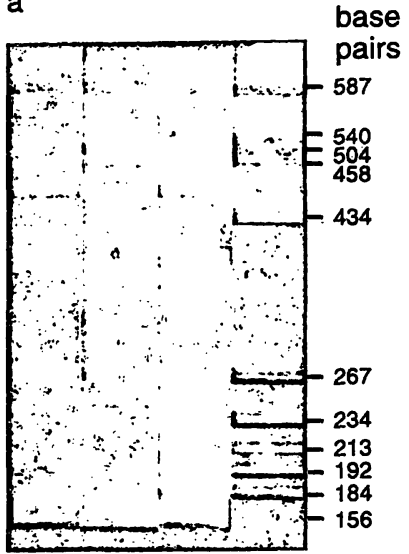

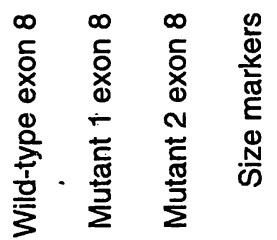

b

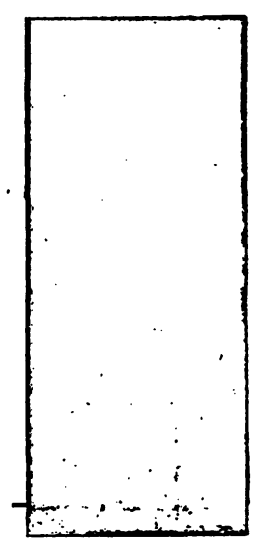

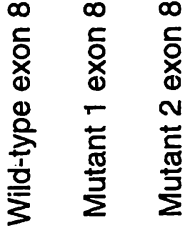

Fig. 4 Influence of the presence of glycerol in polyacrylamide gels on the electrophoretic behaviour of ssDNA fragments. PCR products of wild type and two mutants of exon 8 of the human p53 gene were denatured and applied to $140 \mathrm{~g} / \mathrm{l}$ polyacrylamide gels prepared in $44.5 \mathrm{mmol} / 1$ Tris; $44.5 \mathrm{mmol} / 1$ boric acid; $1 \mathrm{mmol} / \mathrm{l}$ EDTA.

a) $10 \%$ glycerol present in the gel;

b) gel without glycerol.

Double stranded DNA (size indicated) in the samples shows as an intense band at the bottom of each lane. The ladder of a size marker of double stranded DNA is also shown.

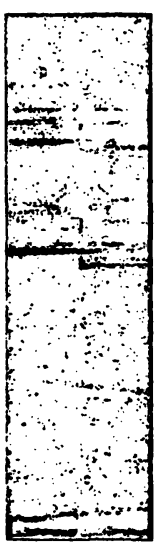

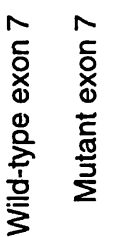

b

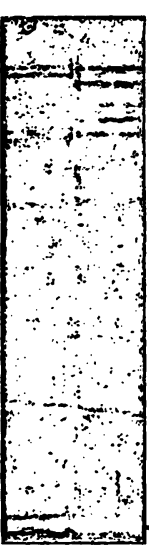

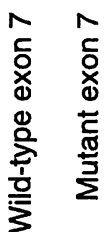

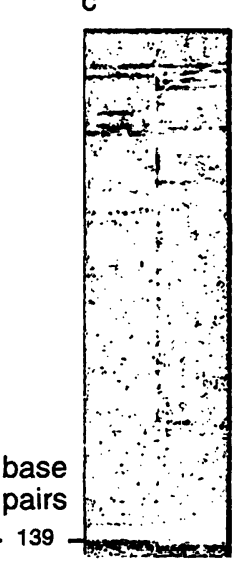

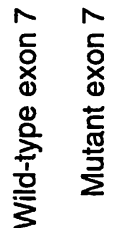

d

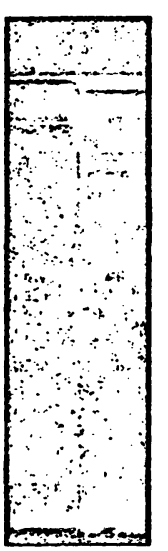

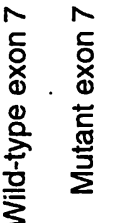

Fig. 5 Influence of different buffer concentrations in $200 \mathrm{~g} / 1$ polyacrylamide gel on the electrophoretic behaviour of ssDNA fragments. PCR products of wild type and two mutants of exon 7 of the human p53 gene were denatured and applied to the gels. The gels were prepared without glycerol, and they contained different concentrations of buffer:

a) $44.5 \mathrm{mmol} / \mathrm{l} \mathrm{Tris;} 44.5 \mathrm{mmol} / \mathrm{l}$ boric acid; $1 \mathrm{mmol} / \mathrm{l} \mathrm{EDTA}$ b) $89.0 \mathrm{mmol} / 1 \mathrm{Tris} ; \quad 89.0 \mathrm{mmol} / 1$ boric acid; $2 \mathrm{mmol} / \mathrm{l} \mathrm{EDTA}$ c) $133.5 \mathrm{mmol} / \mathrm{l} \mathrm{Tris;} 133.5 \mathrm{mmol} / \mathrm{l}$ boric acid; $3 \mathrm{mmol} / \mathrm{l}$ EDTA d) $178.0 \mathrm{mmol} / 1 \mathrm{Tris} ; 178.0 \mathrm{mmol} / \mathrm{l}$ boric acid; $4 \mathrm{mmol} / \mathrm{l}$ EDTA Double stranded DNA (size indicated) in the samples shows as an intense band at the bottom of each lane. 
$\mathrm{mmol} / 1 \mathrm{Tris} ; 89.0 \mathrm{mmol} / 1$ boric acid; $2 \mathrm{mmol} / 1 \mathrm{EDTA}$ ). Raising the acrylamide concentration to $200 \mathrm{~g} / \mathrm{l}$ did not improve band separation significantly, but had the disadvantage that migration rates of single and double stranded DNA molecules were drastically reduced, especially in the presence of glycerol, and, in addition, it was observed that many weak and unexplained bands became visible.

Taken together, when judging the separation capabilities of the 24 different electrophoretic systems by band sharpness, by the number of distinct bands, and by electrophoresis running time, the optimal conditions are 140 $\mathrm{g} / \mathrm{l}$ acrylamide gels with a buffer concentration of 44.5 $\mathrm{mmol} / 1 \mathrm{Tris} ; 44.5 \mathrm{mmol} / \mathrm{l}$ boric acid; $1 \mathrm{mmol} / \mathrm{l} \mathrm{EDTA}$; or $89.0 \mathrm{mmol} / 1$ Tris; $89.0 \mathrm{mmol} / 1$ boric acid; $2 \mathrm{mmol} / \mathrm{l}$ EDTA; addition of $10 \%$ glycerol to these gels can improve the sharpness and separation of bands.

\section{Distinction of mutant and wild-type exons}

In order to judge which gel system is best suited for SSCP analysis the most relevant criterion has to be whether the PCR products of mutants and wild type can be distinguished with certainty. In the present study, 24 electrophoretic conditions were evaluated for their sensitivity in detecting mutants of three exons of human p53. The mutants used in this study were:

(i) one each of exon 5 and 8 from HaCaT cells $(5,6)$ which represent a $\mathrm{C} \rightarrow \mathrm{T}$ single base exchange in codon 179 of one allele (exon 5) and a CC $\rightarrow$ TT two base exchange in codons 281-282 of the other allele (exon 8);

(ii) one mutant of exon 7 from the tissue of a colorectal carcinoma (type of mutation unknown); and

(iii) one mutant of exon 8 from a mamma carcinoma cell line with a $\mathrm{G} \rightarrow \mathrm{A}$ single base exchange in codon 280 which was identified by sequence determination of the PCR product.

As shown by the summary of results in table 1 , detectability of mutants was best in gels with 140 and 200 $\mathrm{g} / 1$ acrylamide. Six out of 24 conditions permitted the unambiguous detection of each of the mutants. Due to the long running time needed in $200 \mathrm{~g} / 1$ gels, however, this gel type was excluded for routine studies. Of the three remaining sets of conditions we normally use 140 $\mathrm{g} / \mathrm{l}$ gel, prepared in buffer $44.5 \mathrm{mmol} / \mathrm{l} \mathrm{Tris} ; 44.5 \mathrm{mmol} / 1$ boric acid; $1 \mathrm{mmol} / 1 \mathrm{EDTA}$ with and/or without $10 \%$ glycerol. For these "selected conditions" it was shown that electrophoresis running time can be reduced without quality loss to only three hours by raising the applied voltage up to $600 \mathrm{~V}$. Due to the large buffer volume of 41 in the lower chamber of the apparatus used, thermostating of the electrophoretic unit was only necessary when the ambient temperature rose above $\approx 25^{\circ} \mathrm{C}$, even at this high voltage. A further voltage increase up to $1000 \mathrm{~V}$ without cooling caused severe "smiling" of the electrophoretic bands.

The "selected conditions" (with and without glycerol) were examined for their general applicability for detecting gene mutations by SSCP analysis. The examples investigated were PCR products of exons $1,5,6$, and 9 of the gene responsible for X-chromosomal adrenoleukodystrophy with chain lengths of 202, 213, 239 and 227 nucleotides, and PCR products (233 nucleotides) of intron 2 of the gene of the haemoglobin $\beta$-chain. All of these mutants have single base exchanges. As shown in figure 6a, of all these arbitrarily chosen examples only one pair of different PCR products, the two wild types nt $666 \mathrm{~T} / \mathrm{T}$ and nt $666 \mathrm{~T} / \mathrm{C}$ of the haemoglobin $\beta$-chain (fig. 6a, lanes 1 and $\mathrm{m}$ ), could not be distinguished in the gel system with glycerol. In the gel without glycerol differences were detected in only two sets of PCR products (fig. 6b, lanes a and $b$, and lanes $d$ and $e$ in comparison with lane c).

\section{Discussion}

SSCP analysis makes use of the fact that single stranded DNA molecules assume distinct three-dimensional structures which cause different electrophoretic mobilities in non-denaturing polyacrylamide gels. In many cases, exchange of a single base results in a change in migration behaviour. In comparison with the corre-

Tab. 1 Number of mutants distinguishable from wild-type exons under the 24 electrophoretic conditions. One mutant each of exons 5 and 7 , and two mutants of exon 8 of human p 53 were analysed by SSCP. The numbers in the last two lines indicate how

many of the total of four mutants were distinguishable from the corresponding wild-type DNA segment under the respective set of electrophoretic conditions.

\begin{tabular}{|c|c|c|c|c|c|c|c|c|c|c|c|c|}
\hline $\begin{array}{l}\text { Acrylamide } \\
\text { Tris*) }\end{array}$ & \multicolumn{4}{|c|}{$75 \mathrm{~g} / 1$} & \multicolumn{4}{|c|}{$140 \mathrm{~g} / 1$} & \multicolumn{4}{|c|}{$200 \mathrm{~g} / \mathrm{l}$} \\
\hline $\begin{array}{l}\text { Tris*) } \\
\text { Boric acid*) } \\
\text { EDTA*) }\end{array}$ & $\begin{array}{c}44.5 \\
44.5 \\
1\end{array}$ & $\begin{array}{c}89.0 \\
89.0 \\
2\end{array}$ & $\begin{array}{c}133.5 \\
133.5 \\
3\end{array}$ & $\begin{array}{c}178.0 \\
178.0 \\
4\end{array}$ & $\begin{array}{c}44.5 \\
44.5 \\
1\end{array}$ & $\begin{array}{c}89.0 \\
89.0 \\
2\end{array}$ & $\begin{array}{c}133.5 \\
133.5 \\
3\end{array}$ & $\begin{array}{c}178.0 \\
178.0 \\
4\end{array}$ & $\begin{array}{c}44.5 \\
44.5 \\
1\end{array}$ & $\begin{array}{c}89.0 \\
89.0 \\
2\end{array}$ & $\begin{array}{c}133.5 \\
133.5 \\
3\end{array}$ & $\begin{array}{c}178.0 \\
178.0 \\
4\end{array}$ \\
\hline $\begin{array}{l}\text { With glycerol } \\
\text { Without glycerol }\end{array}$ & $\begin{array}{l}3 \\
3\end{array}$ & $\begin{array}{l}3 \\
3\end{array}$ & $\begin{array}{l}2 \\
3\end{array}$ & $\begin{array}{l}2 \\
3\end{array}$ & $\begin{array}{l}4 \\
4\end{array}$ & $\begin{array}{l}3 \\
3\end{array}$ & $\begin{array}{l}2 \\
4\end{array}$ & $\begin{array}{l}3 \\
3\end{array}$ & $\frac{2}{4}$ & $\frac{2}{3}$ & $\begin{array}{l}2 \\
4\end{array}$ & $\begin{array}{l}3 \\
4\end{array}$ \\
\hline
\end{tabular}

*) $\mathrm{mmol} / \mathrm{l}$ 
sponding double stranded DNA, which migrates mainly according to chain length, the two complementary single stranded molecules generally show significantly different migration. The electrophoretic mobility of the single strands, both absolute and relative to one another, can be influenced by electrophoretic conditions like pore size of the polyacrylamide gel, buffer concentration and presence of additives like glycerol. Probably any pair of wild type and mutant can be distinguished by carefully adjusting the electrophoretic conditions, and in many cases it will even be possible to adjust the conditions in such a way that the exact type out of a variety of different mutations in a DNA segment can be identified. However, when screening for unknown genetic mutations, the number of different conditions must be kept to a minimum.

The present study examined whether a single set of SSCP analysis conditions might suffice to detect gene mutations in any DNA segment (chain length below 300 base pairs) with high sensitivity. Exons 5, 7 and 8 of the human $\mathrm{p} 53$ gene were chosen as model DNA molecules, and PCR products of the wild-type exons (206, 156 and 139 nucleotides in length) were compared with one or two mutant exons by SSCP analysis. Two of these mutants had single base exchanges, one a double base exchange and one a non-identified alteration in exon 7. Of the 24 different sets of electrophoretic conditions only six permitted the unequivocal detection of all mutants (tab. 1). Interestingly, detection of all mutants was only

A

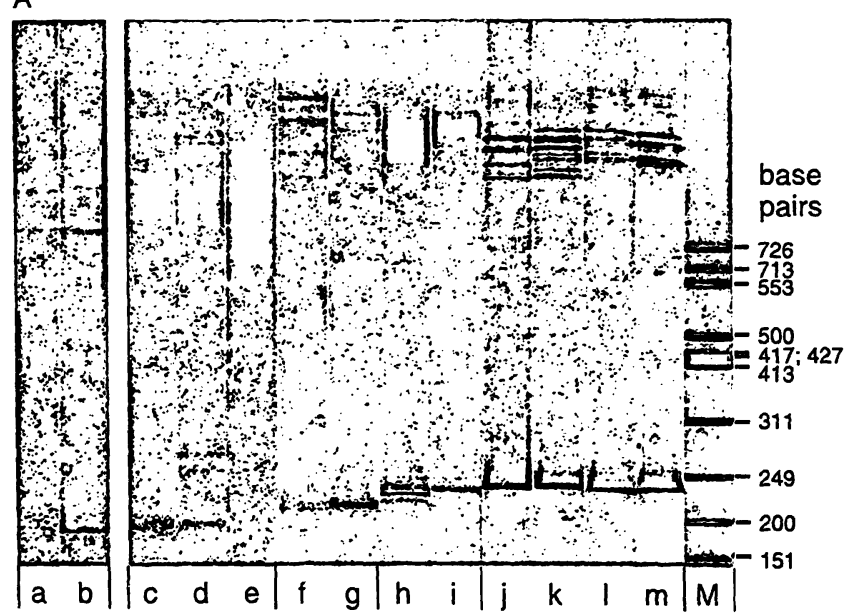

Fig. 6 SSCP analysis of DNA segments of the human $\beta$-globin gene and the gene responsible for $\mathrm{X}$-chromosomal adrenoleukodystrophy using the "selected conditions".

A 233 base pair fragment specific for intron 2 of the human $\beta$ globin gene and segments of 202, 213, 239 and 227 base pairs of exons, 1, 5, 6 and 9 of the gene responsible for X-chromosomal adrenoleukodystrophy were prepared, denatured and applied to 140 $\mathrm{g} / \mathrm{l}$ polyacrylamide gels with $44.5 \mathrm{mmol} / \mathrm{l}$ Tris; $44.5 \mathrm{mmol} / /$ boric acid; $1 \mathrm{mmol} / 1$ EDTA. Gel A contained $10 \%$ glycerol, gel B was without glycerol.

In lanes a to i, PCR products corresponding to segments of the gene responsible for $\mathrm{X}$-chromosomal adrenoleukodystrophy were applied:

a) wild-type exon 1 ; achieved when gel slabs with high acrylamide concentrations, 140 or $200 \mathrm{~g} / \mathrm{l}$, were used, whereas a screening of current publications on SSCP analysis of p53 mutants showed that gels with acrylamide concentrations in the range of 60-80 g/l are much more often employed. Table 1 further indicates that, in the' 140 and $200 \mathrm{~g} / 1$ gels, the concentration of the buffer used for gel preparation has no significant influence on mutant detectability. Addition of $10 \%$ glycerol decreased the detectability of mutants of p53 exons in several of the sets of electrophoretic conditions, especially in 75 and $200 \mathrm{~g} / 1$ gels (tab. 1). On the other hand, in SSCP studies on other DNA fragments, we observed better detectability in the presence of glycerol. Therefore, we routinely perform SSCP screening both with and without addition of glycerol.

When the "selected electrophoretic conditions" (140 g/l acrylamide, $44.5 \mathrm{mmol} / 1 \mathrm{Tris} ; 44.5 \mathrm{mmol} / 1$ boric acid; $1 \mathrm{mmol} / 1 \mathrm{EDTA}$, without and with glycerol, ambient temperature between 20 and $24^{\circ} \mathrm{C}$ ) were tested in the SSCP analysis of an arbitrarily chosen set of mutant DNA fragments, the outcome was entirely satisfactory: all but one of seven mutants were detected when glycerol was present in the gel (fig. 6a).

In conclusion, by evaluating 24 different sets of electrophoretic conditions for their ability to distinguish wildtype and genetically altered DNA by SSCP analysis, the clear result was obtained that a better distinction is achieved when gels with high acrylamide concentrations, i. e. 140 or $200 \mathrm{~g} / \mathrm{l}$, are used. As the electrophore-

B

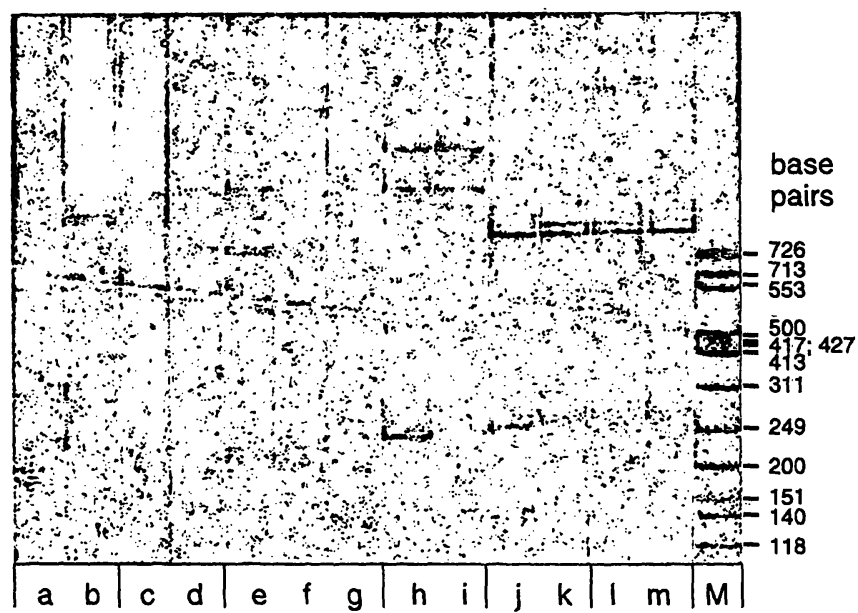

b) mutant exon 1 ;

c) wild-type exon 5;

d) wild-type and mutant exon 5 (heterozygosity);

e) mutant exon 5 (homozygosity);

f) wild-type exon 9 ;

g) mutant exon 9 ;

h) wild-type exon 6 ;

i) mutant exon 6 .

In lanes $\mathrm{j}$ to $\mathrm{m}, \mathrm{PCR}$ products corresponding to a segment (233 base pairs) of intron 2 of the human $\beta$-globin gene were applied:

j) IVS-2 nt $745 \mathrm{C}>\mathrm{T}$;

k) IVS-2 nt $745 \mathrm{C}>\mathrm{T} / \mathrm{WT}$ nt $666 \mathrm{~T}$;

l) WT nt $666 \mathrm{~T} / \mathrm{T}$;

m) WT nt $666 \mathrm{~T} / \mathrm{C}$. 
sis running time is significantly longer in $200 \mathrm{~g} / \mathrm{l}$ gels, the $140 \mathrm{~g} / 1$ gels may be preferred. In the experiments with p53 mutants no clear-cut effect was found for the addition of $10 \%$ glycerol, but, when studying a series of PCR products of other genes, the distinguishability of DNA fragments with single base exchanges was tremendously improved by adding glycerol to the gel. Thus, glycerol may, depending on the respective example, improve or decrease the detectability of mutations. It is therefore advisable to perform the SSCP analysis both with and without glycerol addition. Though it is clear that no single set of electrophoretic conditions can guar-

\section{References}

1. Grompe M. The rapid detection of unknown mutations in nucleic acids. Nature Genet 1993; 5:111-7.

2. Orita M, Suzuki Y, Sekiya T, Hayashi K. Rapid and sensitive detection of point mutations and DNA polymorphisms using the polymerase chain reaction. Genomics $1989 ; 5: 874-9$.

3. Ainsworth PJ, Surth LC, Culture MMB. Diagnostic single strand conformational polymorphism, (SSCP): a simplified non-radioisotopic method as applied to a Tay-Sachs Bl variant. Nucl Acids Res 1991; 19:405-6.

4. Yap EP, McGee JO. Nonisotopic SSCP detection in PCR products by ethidium bromide staining. Trends Genet 1992; 8:49.

5. Boukamp P, Petrussevska RT, Breitkreuz D, Hornung J, Markham A, Fusenig NE. Normal keratinization in a spontaneously immortalized aneuploid human keratinocyte cell line. J Cell Biol 1988; 106:761-71.

6. Lehman TA, Modali R, Boukamp P, Stanek J, Bennett WP, Welsh JA, et al. p53 Mutations in human immortalized epithelial cell lines. Carcinogenesis 1993; 14:833-9.

7. Sambrook J, Fritsch EF, Maniatis T. Molecular cloning: a laboratory manual. Cold Spring Harbor: Cold Spring Harbor Laboratory Press, 1989.

8. Unsal H, Yakicier C, Marcais C, Kew M, Volkmann M, Zentgraf $\mathrm{H}$, et al. Genetic heterogeneity of hepatocellular carcinoma. Proc Natl Acad Sci USA 1994; 81:822-6. antee the detection of all mutations of any gene, our results indicate that the described set of "selected conditions" is in general quite reliable in detecting even small differences like single base exchanges in DNA fragments up to chain length of at least 200 to 300 nucleotides. These conditions should therefore prove particularly useful in screening studies for unknown mutants.

\section{Acknowledgements}

We are very grateful to Prof. N. E. Fusenig, Deutsches Krebsforschungszentrum, Heidelberg, for providing the HaCaT cell line.

9. Chozick BS, Weicker ME, Pezzullo JC, Jackson CL, Finkelstein SD, Ambler MW, et al. Pattern of mutant p53 expression in human astrocytomas suggests the existence of alternate pathways of tumorigenesis. Cancer 1994; 73:406-15.

10. Buchman VL, Chumakov PM, Ninkina NN, Samarina OP, Georgiev GP. A variation in the structure of the protein-coding region of the human p53 gene. Gene 1988; 70:245-52.

11. Braun A, Ambach H, Bichlmaier R, Kammerer S, Roscher AA. Population study of a sequence polymorphism in intron 2 of the human $\beta$-globin gene. Hum Genet 1995; 95:352.

12. Riesner D, Steger G, Zimmat R, Owens RA, Wagenhöfer M, Hillen W, Vollbach S, Henco K. Temperature-gradient gel electrophoresis of nucleic acids: analysis of conformational transitions, sequence variations, and protein-nucleic acid interactions. Electrophoresis 1989; 10:377-89.

Received July 20/October 20, 1995

Corresponding author: Prof. Dr. Edwin Fink, Abteilung für Klinische Chemie und Klinische Biochemie in der Chirurgischen Klinik und Poliklinik, Nußbaumstraße 20, D-80336 München, Germany 
